KRZYSZTOF TARKA

Uniwersytet Opolski, Instytut Historii

\title{
ZMAGANIA O WOLNOŚĆ. SPRAWA UCIECZKI ANTONIEGO KLIMOWICZA W 1954 R.
}

Zablokowanie możliwości swobodnego wyjeżdżania za granicę było jednym z elementów systemu komunistycznego. Totalitarne państwo chciało ściśle kontrolować i nadzorować ruch zagraniczny, decydując, kto, kiedy i na jakich warunkach może wyjechać z kraju. Mimo uszczelnienia granic nie udało się wyeliminować prób nielegalnego ich przekraczania bądź odmowy powrotu do kraju z czasowego wyjazdu legalnego. Ministerstwo Spraw Wewnętrznych odnotowało w latach 1944-1968 ogółem 32416 osób, które zbiegły lub odmówiły powrotu do Polski. Według tych danych blisko $2 / 3$ spośród nich znalazło się w trzech państwach Europy Zachodniej. Najwięcej w Republice Federalnej Niemiec (11 018), następnie we Francji (5978) i Wielkiej Brytanii (3704) ${ }^{1}$.

Na początku lat pięćdziesiątych XX w. bodaj najliczniejszą grupę zawodową wśród uciekinierów stanowili marynarze. W latach 1952-1954 ze statków Polskiej Marynarki Handlowej, Rybołówstwa Morskiego i Żeglugi Śródlądowej „zdezerterowało” 191 pracowników (według przytoczonego powyżej zestawienia za granicę zbiegło wówczas lub odmówiło powrotu do kraju ogółem 600 osób) ${ }^{2}$.

Legalne wyjazdy na Zachód miały wówczas wręcz jednostkowy charakter, a Polska Ludowa stała się dla milionów jej mieszkańców „krajem bez wyjścia". W 1954 r. na prywatny wyjazd czasowy do państw kapitali-

${ }^{1}$ Streszczenie z 15 V 1969 r. zestawień statystycznych zarejestrowanych w Biurze „C” osób, które zbiegły lub odmówity powrotu do kraju w latach 1944-1968, w: M. Bortlik-Dźwierzyńska, M. Niedurny, Uciekinierzy z PRL, Katowice-Warszawa 2009, s. 310-313.

${ }^{2}$ Notatka informacyjna z 20 XII 1954 r. dotyczaca dezercji ze statków Polskiej Marynarki Handlowej, Rybołówstwa Morskiego i Żeglugi Śródlądowej, w: M. Bortlik-Dźwierzyńska, M. Niedurny, op. cit., s. 242 (por. też ibidem, s. 306-307). 
stycznych zezwolono zaledwie 52 osobom. Podobna liczba osób uzyskała zgodę na indywidualną emigrację na Zachód na stałe ${ }^{3}$. W tym samym roku - według oficjalnych danych - za granicę zbiegło lub odmówiło powrotu do kraju 125 osób. W zdecydowanej większości byli to ludzie młodzi. Aż 80 spośród nich nie ukończyło 30 lat, a zaledwie 4 osoby miały ponad 50 lat. Największą grupę stanowili mieszkańcy województwa gdańskiego (20 osób) oraz warszawskiego (13 osób), wrocławskiego (12) i szczecińskiego (11). W przypadku 24 osób brak danych ${ }^{4}$.

Jednym z najbardziej dramatycznych przypadków była ucieczka Antoniego Klimowicza, „ślepego” pasażera ze statku „Jarosław Dąbrowski”. Ta ciekawa sprawa miała złożony i skomplikowany pod względem prawnym charakter. Odbiła się również na stosunkach polsko-brytyjskich. Przypadek Klimowicza pokazuje reakcje i zachowanie władz PRL wobec uciekinierów. Wydaje się, że wpłynął on także na kształtowanie polityki brytyjskiej wobec zbiegów z krajów komunistycznych. Ucieczka młodego Polaka odbiła się równocześnie głośnym echem wśród emigrantów polskich w Wielkiej Brytanii ${ }^{5}$.

Po południu 28 lipca 1954 r. angielscy dokerzy, rozładowujący w porcie londyńskim statek „Jarosław Dąbrowski”, znaleźli w jednej z ładowni nielegalnego pasażera. Uciekinier był skrajnie wycieńczony. Kilka po-

${ }^{3}$ Szerzej: D. Stola, Kraj bez wyjścia? Migracje z Polski 1949-1989, Warszawa 2010, s. 23-48.

${ }^{4}$ M. Bortlik-Dźwierzyńska, M. Niedurny, op. cit., s. 303-317. Tematem ucieczek z PRL zajmowali się również inni autorzy: J. Drużyńska, J. M. Jankowski, Ucieczki specjalnego znaczenia, Poznań 2011; T. S. Gałązka, Ucieczki rybaków z Gdyni w latach 1948-1959, w: Korzenie Gdyni, cz. 4, Gdynia 2004, s. 78-82; A. Kochański, O wyrokach śmierci w stanie prawie wojennym (o żołnierzach Wojska Polskiego skazanych na śmierć za próbę ucieczki na Zachód), „Polska 1944/45-1989. Studia i Materiały” 4, 1999, s. 353-359; W. Krzywicki, Ucieczki z Peerelu, „Karta” 1996, 16, s. 121-122; A. Lutogniewski, Ucieczka , ,Karta” 2005, 46, s. 136-142; W.J. Modrakowski, Ucieczki z PRL - kto, jak, dlaczego? (aspekty prawno-kryminologiczne), Warszawa 1992; L. Pawlikowicz, Tajny front zimnej wojny. Uciekinierzy z polskich służb specjalnych 1956-1964, Warszawa 2004; T. Pióro, Ucieczki oficerów Ludowego Wojska Polskiego w latach 1948-1990, „Więź” 1999, 12, s. 124-139; J. Skoczylas, W. Lada, Wielkie ucieczki. O ludziach, którzy zbiegli z PRL-u, Warszawa 2010; K. Tarka, Sprawa marynarzy z „Puszczyka” z 1954 r. Przyczynek do historii ucieczek z PRL, „Klio” 2012, 3 (22), s. $115-132$.

${ }^{5}$ O sprawie Klimowicza zob. teksty zamieszczone w Internecie: $\langle$ http://fds.oup. com/www.oup.co.uk/pdf/0-19-923150-8.pdf $\rangle,\langle$ http://fee.org/the_freeman/detail/ habeas-corpus-to-the-rescue/ $\rangle$, 〈http://hansard.millbanksystems.com/written answers/1954/oct/28/antoni-klimowicz-writ-of-habeas-corpus > (dostęp: 9 XI 2012). Zob. też: J. Linowski, Wielka Brytania w polityce zagranicznej Polski w latach 1945-1956, Toruń 2001, s. 245. Po latach historię Klimowicza opisała reporterka „Dziennika Bałtyckiego” Dorota Abramowicz, Wielka ucieczka Antka K., ,Dziennik Bałtycki” 11 VI 2004, 135, s. 18-19. 
przednich dni, tj. od chwili, gdy statek wypłynął z Gdyni, spędził on w zamknięciu, bez jedzenia i picia. Polscy marynarze wyciągnęli go na pokład i zaprowadzili do mesy. Zbieg początkowo podawał się za Niemca. O znalezieniu „ślepego” pasażera kapitan statku Mirosław Głowacki zawiadomił Konsulat Generalny PRL w Londynie. Niebawem na pokładzie pojawili się urzędnicy Immigration office, zaalarmowani przez robotników portowych. Zgodnie z procedurą przesłuchali uciekiniera, którym okazał się młody Polak, Antoni Klimowicz. Zbieg oddał Anglikom swoje dokumenty i prosił o udzielenie mu azylu w Wielkiej Brytanii. Gdy na statek dotarł polski wicekonsul Kazimierz Maciejkowicz, nakazał kapitanowi, aby zdecydowanie sprzeciwił się ewentualnej próbie zabrania Klimowicza. Jeden z Anglików próbował skontaktować się z przełożonymi, ale ponieważ było już zbyt późno i nikogo nie zastał w biurze, pozostawił uciekiniera do rozstrzygnięcia sprawy pod opieką kapitana. Zapowiedział, że zjawi się na statku następnego dnia rano ${ }^{6}$.

Jeszcze tego samego dnia, późnym wieczorem, Klimowicza przesłuchiwał urzędnik konsulatu Edmund Drożdż. Uciekinier ujawnił swoje dane personalne (urodził się w 1931 r.). Jak się okazało, był byłym marynarzem. W styczniu 1954 r. został zwolniony z pracy. Przez kilka miesięcy bezskutecznie próbował znaleźć zatrudnienie na jakimś statku. Ostatecznie postanowił uciec do Wielkiej Brytanii. W tym celu wieczorem 22 lipca 1954 r. w Gdyni przedostał się na statek „Jarosław Dąbrowski”, na którym zresztą wcześniej pływał. Strażnikom stojącym przy trapie pokazał książeczkę żeglarską z nieaktualnym wpisem. Na statku schował się w jednej z ładowni. Drożdż zarzucał Klimowiczowi nielegalne przekroczenie granicy. Tłumacząc mu niewłaściwość jego postępowania, próbował go również odwieść od starania się o uzyskanie azylu. Nie przyniosło to jednak żadnego skutku. Zbieg odmówił też podpisania protokołu przesłuchania ${ }^{7}$.

Ponieważ obawiano się, że Klimowicz może podjąć próbę ucieczki, zamknięto go w kajucie, pod nadzorem jednego z członków załogi. Krótko przed północą konsulat zawiadomił kapitana, że zbieg miał być poszukiwany w Polsce za popełnienie pospolitego przestępstwa. Wysuwając oskarżenia pod adresem Klimowicza, chciano przeciwdziałać ewentualnemu zamiarowi wydania przez Brytyjczyków zezwolenia na jego zejście

${ }^{6}$ Archiwum Ministerstwa Spraw Zagranicznych (AMSZ), Departament III (D III), zespół 9, wiązka 30, teczka 389, Raport M. Głowackiego kapitana s/s „Jarosław Dąbrowski” w sprawie „ślepego” pasażera - Klimowicz Antoni, k. 11; ibidem, Notatka służbowa K. Maciejkowicza dla ambasadora PRL w Londynie E. Milnikiela dot. nielegalnego pasażera ze statku s/s „Jarosław Dąbrowski”, k. 6-7.

${ }^{7}$ Ibidem, Protokół przesłuchania nielegalnego pasażera na statku s/s ,J. Dąbrowski” sporządzony w dniu 28 VII 1954 r., k. 14-15. 
na ląd. Jednocześnie konsulat poinstruował kapitana, że uciekinier, jako polski obywatel, nie może być wydany bez zgody władz polskich ${ }^{8}$.

O ucieczce Klimowicza Ministerstwo Spraw Zagranicznych niezwłocznie zawiadomiło najwyższe władze partyjno-państwowe PRL. Informacje w tej sprawie na bieżąco trafiały między innymi na biurka I sekretarza Komitetu Centralnego Polskiej Zjednoczonej Partii Robotniczej Bolesława Bieruta, przewodniczącego Rady Państwa Aleksandra Zawadzkiego czy premiera PRL Józefa Cyrankiewicza?.

Na miejscu z ramienia polskiej placówki nad Tamizą sprawą zajął się brytyjski adwokat - Gaster. Nazajutrz po wykryciu zbiega zadzwonił do Immigration Office. Jak się okazało, sprawa została już przekazana do Home Office (czyli resortu spraw wewnętrznych). Gaster próbował się skontaktować z odpowiednim urzędnikiem, ale bez skutku. Występując w imieniu Konsulatu Generalnego PRL, zastrzegł sobie uczestnictwo we wszelkich ewentualnych działaniach podjętych przez władze brytyjskie. Ostrzegł też swojego rozmówcę z brytyjskiego Ministerstwa Spraw Wewnętrznych, że wolałby, aby sprawa nie nabrała charakteru sporu międzynarodowego. Po południu do Gastera zadzwonił jeden z dyrektorów departamentu w Home Office. Władze brytyjskie były wyraźnie niezadowolone z wmieszania się w sprawę adwokata. Na podstawie rozmowy Gaster nie mógł się jednak zorientować, „czy Home Office podejmie jakąś akcję, czy też jej zaniecha"10.

Urzędnik imigracyjny pojawił się na statku ponownie dopiero 24 godziny po odnalezieniu uciekiniera. W obecności kapitana oświadczył Klimowiczowi, że władze brytyjskie nie wydały mu zgody zejścia na ląd, nie znalazły też podstaw do traktowania go w sposób odmienny od innych „ślepych" pasażerów. Oznaczało to, że zbieg ma wrócić tym samym statkiem do Polski. Na potwierdzenie tych słów Anglik wręczył odpowiedni dokument Klimowiczowi i kapitanowi ${ }^{11}$. W tej sytuacji wydawało się, że nic już nie może uratować młodego Polaka, a próba ucieczki będzie miała dla niego fatalny finał.

30 lipca po południu zakończono załadunek i załoga polskiego statku szykowała się do powrotnego rejsu do Gdyni. Po północy, o godzinie 1.30, w dniu 31 lipca „Jarosław Dąbrowski” odbił od nabrzeża. Jednak

\footnotetext{
${ }^{8}$ Ibidem, Raport M. Głowackiego, k. 11; ibidem, Notatka służbowa K. Maciejkowicza, k. 6-7.

${ }_{9}^{9}$ Ibidem, Wyciąg korespondencyjny z Londynu z 29 VII 1954, k.1. Zob. też: ibidem, Wyciągi korespondencyjne z Londynu z 30 i 31 VII oraz 2, 3 i 9 VIII 1954, k. 15, 17, 20.

10 Ibidem, Notatka służbowa radcy Ambasady PRL M. Żułkosia z 29 VII 1954, k. 2-3.

${ }^{11}$ Ibidem, Notatka służbowa K. Maciejkowicza, k. 7; ibidem, Raport M. Głowackiego, k. 11 .
} 
już godzinę później motorówka policyjna zatrzymała statek na Tamizie w pobliżu Blackwall we wschodnim Londynie. Na pokład wszedł urzędnik imigracyjny w towarzystwie komisarza i kilku policjantów. Zażądali oni wydania Klimowicza. Kapitan sprzeciwił się temu, powołując się na poprzednie pisemne zarządzenie władz brytyjskich. Domagał się również zawiadomienia o incydencie polskiego konsulatu. W tym celu około 4 nad ranem dwóch oficerów ze statku udało się policyjną motorówką na ląd. Po telefonie do konsulatu powrócili na statek. „Jarosław Dąbrowski” zacumował w pobliżu Woolwich, gdzie pozostał pod stałym nadzorem policji.

$\mathrm{W}$ południe przedstawiciel urzędu imigracyjnego w towarzystwie policji zakomunikował kapitanowi, że statek ma pozostać przy nabrzeżu do czasu ostatecznego wyjaśnienia sprawy. 0 godzinie 16.25 na „Jarosława Dąbrowskiego" przybył wicekonsul Maciejkowicz. Zgodnie z instrukcją MSZ polecił kapitanowi, aby nie wydawał zbiega i nie podejmował samodzielnie żadnych decyzji. W razie próby „zdjęcia” Klimowicz ze statku kapitan miał ustąpić tylko pod groźbą użycia siły przez brytyjską policję ${ }^{12}$.

W sprawie Klimowicza MSZ wezwało na rozmowę radcę ambasady brytyjskiej w Warszawie. Zalecono też polskiej placówce nad Tamizą, aby „dla podsłuchu angielskiego rozmowy telefonicznej między MSZ a Ambasadą skomentować, że «solidna Anglia i solidna policja brytyjska» pod naciskiem reakcyjnej emigracji daje się sprowadzić do poziomu Li Syng Mana [pogardzany w PRL prezydent Korei Południowej - K. T.] i naraża się na ośmieszenie wobec całego świata"13. Aby „zmiękczyć” Anglików w sprawie „ślepego" pasażera, Warszawa chwytała się więc różnych sposobów.

W tym samym czasie ambasador PRL Eugeniusz Milnikiel trzykrotnie interweniował w sprawie Klimowicza w Foreign Office. Po raz pierwszy polski dyplomata rozmawiał z podsekretarzem stanu w brytyjskim MSZ Johnem Wardem oraz z dyrektorem Departamentu Północnego Harrym Hohlerem o godzinie 11.30. Ambasador dopytywał się o kulisy nocnej interwencji policji: kto i dlaczego wydał polecenie zatrzymania polskiego statku po odbiciu od brzegu. Ward wyraźnie zaambarasowany wyjaśniał, iż minister spraw wewnętrznych ponownie rozważył sprawę i postanowił dać Klimowiczowi możność apelacji od poprzedniej decyzji. W tym celu zatrzymano statek, chcąc umożliwić zbiegowi zejście na ląd. W nowej sytuacji Ward prosił ambasadora, aby ten nakazał kapitanowi statku

${ }^{12}$ Ibidem, Notatka służbowa K. Maciejkowicza, k. 8; ibidem, Raport M. Głowackiego, k. 11-12.

${ }^{13}$ Ibidem, Instrukcje przekazane telefonicznie w dniu 31 VII 1954 r. ambasadorowi E. Milnikielowi przez min. spraw zagranicznych S. Skrzeszewskiego o postępowaniu w sprawie „ślepego” pasażera na statku „Jarosław Dąbrowski” (uzgodnione z tow. F. Mazurem), k. 5. 
wydanie uciekiniera. Milnikiel jednoznacznie stwierdził, że nie wyda takiego polecenia. Anglik tłumaczył, że statek znajduje się na brytyjskich wodach terytorialnych, pod brytyjską jurysdykcją i kapitan winien wykonywać polecenia władz brytyjskich. Ambasador odpowiedział, że żądanie od niego, aby zezwolił Klimowiczowi zejść na teren brytyjski, nie ma podstaw prawnych. Podkreślił, że "Jarosław Dąbrowski” jest polskim statkiem, na którym nielegalnie znajdował się polski obywatel, ścigany ponadto w kraju za pospolite przestępstwa. Dodał, iż człowiek ten nie zszedł na ląd, nie opuścił polskiego statku, nie popełnił żadnego przestępstwa wobec władz brytyjskich. Na zakończenie swojej wizyty Milnikiel zasugerował, iż upór Anglików w sprawie Klimowicza może popsuć dobrze układające się stosunki między Londynem a Warszawą: „Chciałbym, aby stosunki między naszymi rządami - stwierdził ambasador - układały się jak najpomyślniej. Jesteśmy w przededniu zakończenia naszych rozmów handlowych i finansowych regulujących sprawę odszkodowań za własność brytyjską w Polsce. Stosunki nasze rozwijają się raczej pomyślnie, po cóż więc wprowadzać jakiekolwiek momenty zadrażnienia"14.

Trzy godziny później Milnikiel ponownie przyszedł do Foreign Office. Po konsultacji z Warszawą zakomunikował krótko, że rząd PRL nie zgadza się na udzielenie kapitanowi statku zgody na zejście Klimowicza na ląd. Po oświadczeniu ambasadora „zapadła głęboka cisza”. Po dłuższej chwili Ward powiedział, że stanowisko władz polskich stwarza „dość skomplikowaną sytuację". Milnikiel twierdził, iż zarówno z punktu widzenia prawa polskiego, jak i prawa międzynarodowego sprawa Klimowicza jest ,jasna i wyraźna”. Ponownie pytał, „dlaczego i po co wytwarza się sytuację napięcia, komu jest to potrzebne i jakiemu celowi to ma służyć". Sugerował, że rząd brytyjski niepotrzebnie ulega wpływom „wrogich” Polsce „kół emigranckich" lub „jakimś trzecim nieznanym mi czynnikom”. Podsumowując, zaznaczył: „kierunek żądań władz brytyjskich nie idzie po linii łagodzenia sprawy, a w kierunku jej zaostrzania". Apelował, aby Londyn wrócił do pierwotnej ,jedynie słusznej koncepcji”"15.

O godzinie 17.45 Milnikiel po raz trzeci zjawił się w Foreign Office, tym razem na zaproszenie Warda. Podsekretarz stanu w brytyjskim MSZ wręczył polskiemu dyplomacie aide-mémoire precyzujące stanowisko Londynu w sprawie Klimowicza. W dokumencie przypomniano, że początkowo odmówiono mu zezwolenia zejścia na ląd i udzielenia azylu. Jednak „kilka osób" (mimo pytania Milnikiela Ward nie ujawnił ich personaliów) wystąpiło z apelem do ministra spraw wewnętrznych, uważając, iż „sprawa ta

${ }^{14}$ Ibidem, Notatka E. Milnikiela z rozmów w Foreign Office w dniu 31 VII 1954,k. 25-26.

${ }^{15}$ Ibidem, k. 27-28. 
wymaga dalszego rozważenie i aby umożliwić dalsze zbadanie sprawy, Minister zadecydował udzielić Klimowiczowi zezwolenia zejścia na ląd. [--] Podczas gdy Rząd Jej Królewskiej Mości rozważa, czy ma skorzystać czy też nie ze swego suwerennego prawa udzielenia azylu osobie, która znajduje się w jurysdykcji korony, jest nie do pomyślenia, aby ubiegający się był zabrany siłą spod tej jurysdykcji". Równocześnie Sędzia Główny (lord Chief Justice of England and Wales) lord Rayner Goddard na podstawie Habeas Corpus Act wydał kapitanowi statku nakaz doprowadzenia Klimowicza do sądu we wtorek 3 sierpnia 1954 r. na godzinę 11. W tej sytuacji rząd JKM oczekiwał, że Klimowicz zostanie przekazany władzom brytyjskim w celu zapewnienia wykonania nakazu sądu. Milnikiel, komentując dokument, stwierdził, że sędzia nie może wydać kapitanowi nakazu doprowadzenia do brytyjskiego sądu polskiego obywatela, który znajduje się na polskim statku (w rozumieniu prawa „cząstce terytorium polskiego”). Podkreślił, iż uciekinier nie znalazł się na terytorium brytyjskim, dlatego podlega wyłącznie jurysdykcji prawa polskiego. Na zakończenie Ward zwrócił uwagę, że od kapitana wymaga się posłuszeństwa wobec brytyjskich przepisów prawnych. W odpowiedzi ambasador zaznaczył, że od kapitana polskiego statku wymaga się również posłuszeństwa wobec prawa polskiego ${ }^{16}$. Stanowiska stron uległy zaostrzeniu, a sprawa Klimowicza coraz wyraźniej zmierzała ku przesileniu.

W nocy 31 lipca stojący przy nabrzeżu statek został otoczony przez dziesięć policyjnych łodzi motorowych. W akcji osobiście wziął udział szef londyńskiej policji John Nott-Bower oraz 120 policjantów. Ponadto w pobliże polskiego statku podpłynął kontrtorpedowiec. Drugi stał w pogotowiu w bazie Chatham u ujścia Tamizy. Demonstracja siły miała zniechęcić załogę "Jarosława Dąbrowskiego" do stawiania oporu. Komendant policji w towarzystwie urzędnika imigracyjnego wszedł na pokład i zażądał wydania Klimowicza. Wręczył też kapitanowi plik dokumentów sądowych dotyczących uciekiniera. Kapitan, działając w myśl instrukcji, odmówił wydania zbiega i zażądał obecności konsula. Nott-Bower, nie czekając na zawiadomienie konsula, zarządził przeprowadzenie rewizji na statku. Gdy kapitan odmówił otwarcia drzwi kabiny, w której przetrzymywany był uciekinier, brytyjscy policjanci wyłamali je za pomocą łomu i toporów strażackich. Załoga statku próbowała uniemożliwić wyprowadzenie zbiega. Doszło do przepychanek. Akcja „odbicia” Klimowicza trwała pół godziny i krótko przed północą policja opuściła statek. Kilka godzin później kapitanat portu wydał zgodę na odpłyniecie statku.

${ }^{16}$ Ibidem, k. 28-29; ibidem, Tłumaczenie aide-mémoire doręczonego amb. E. Milnikielowi przez Foreign Office 31 VII 1954 r. o godz. 18, k. 4. 
Rano 1 sierpnia „Jarosław Dąbrowski” był już na pełnym morzu ${ }^{17}$. Ostatecznie dzięki spektakularnej akcji Klimowicz został uratowany, choć nie był to jeszcze koniec sprawy.

Jakie były przyczyny nieoczekiwanego zwrotu w postępowaniu władz brytyjskich? Do zmiany decyzji w sprawie Klimowicza przyczyniła się zorganizowana akcja podjęta przez polskich emigrantów. W południe 30 lipca do redakcji „Dziennika Polskiego i Dziennika Żołnierza” dotarła wiadomość, że angielscy dokerzy odkryli na pokładzie statku ,Jarosław Dąbrowski" polskiego uciekiniera. Zbieg został uwięziony na statku. Po powrocie do kraju groził mu proces i kilkuletni wyrok. Dramatyczny los nielegalnego pasażera zmobilizował emigrantów do działania. Redakcja londyńskiego „Dziennika Polskiego” natychmiast zawiadomiła biuro generała Władysława Andersa oraz prezesów Stowarzyszenia Polskich Kombatantów Stefana Soboniewskiego i Zjednoczenia Polskiego w Wielkiej Brytanii Stanisława Lisa. Dwóch dziennikarzy udało się też na nabrzeże w okolice mostu Tower, gdzie stał zacumowany polski statek. Jeden z nich wszedł nawet na pokład i próbował porozmawiać ze zbiegiem, ale spotkał się z odmową i wyzwiskami ze strony załogi. Około godziny 15.30 prezes Związku Dziennikarz RP Bolesław Wierzbiański i redaktor Ludwik Rubel z „Dziennika Polskiego" pospieszyli do parlamentu i zwrócili się do trzech posłów z prośbą o interwencję. Dotarli też do wiceministra spraw wewnętrznych Hugh Lucas-Tooth'a, który obiecał, że zawiadomi o sprawie swego przełożonego, tj. ministra Davida Maxwella Fyfe'a.

Wieczorem przed bramą portu kilkadziesiąt osób - większość z nich stanowili polscy emigranci - protestowało przeciwko decyzji władz brytyjskich, żądając uwolnienia Klimowicza. Wydawało się, że niedoszłego uciekiniera nic już jednak nie uratuje. Około godziny 21 Wierzbiański, Rubel oraz redaktor naczelny „Dziennika Polskiego” Tadeusz Horko próbowali uzyskać jakieś informacje w Home Office. Dowiedzieli się jedynie, że sprawa Klimowicza jest nadal rozpatrywana. Równocześnie Adam Ciołkosz, przewodniczący Polskiej Partii Socjalistycznej w Wielkiej Brytanii, za pośrednictwem działaczy brytyjskich związków zawodowych zaalarmował byłego labourzystowskiego ministra spraw wewnętrznych Herberta Morrisona, a ten interweniował w Home Office. Desperacką próbę ratowania zbiega podjął również mecenas Jan Jaxa-Dębicki, składając na niego skargę: podczas poprzedniego pobytu w Londynie Klimowicz miał przywłaszczyć sobie 10 funtów i 13 szylingów. Pod pozorem fikcyjnego oskarżenia adwokat chciał wydostać uciekiniera ze statku. Policja uznała

${ }^{17}$ Ibidem, Raport M. Głowackiego, k. 12-13. Zob. też Klimowicz uratowany - 120 policjantów w akcji, „Dziennik Polski i Dziennik Żołnierza” (dalej: DPDŻ) 1954, 182, s. 1, 4. 
jednak zarzut za bezpodstawny. Tuż przed północą tłum Polaków zgromadzonych w porcie próbował nawet przetrzymać jako „zakładników” dwóch członków załogi powracających na statek. Uratowała ich jednak zdecydowana interwencja brytyjskiej policji. Choć „Jarosław Dąbrowski” z Klimowiczem na pokładzie odbił od nabrzeża, to niebawem został zatrzymany przez policję.

Nazajutrz przed południem delegacja Zjednoczenia Polskiego z wiceprzewodniczącym Henrykiem Archutowskim i sekretarzem Pawłem Hęciakiem interweniowała w Home Office w sprawie azylu dla Klimowicza (w tym samym czasie ambasador Milnikiel protestował w Foreign office przeciwko zatrzymaniu statku). Po południu Federacja Wolnych Dziennikarzy wysłała do premiera Winstona Churchilla depeszę popierającą akcję polskich emigrantów. Przedstawiciel Zjednoczenia Polskiego rozmawiał również z dyrektorem departamentu imigracyjnego Home Office, prosząc o szybkie załatwienie sprawy. Podkreślił, że dopóki Klimowicz jest w rękach kapitana statku, nie zdobędzie się na prośbę o azyl, ponieważ jest sterroryzowany. Ze swej strony mecenas Jaxa-Dębicki podejmował starania o wydanie pozwu na podstawie Habeas Corpus Act. O godzinie 17 Home Office ogłosiło, iż lord Goddard wydał pozew nakazujący kapitanowi statku "Jarosław Dąbrowski” dostarczenie Klimowicza do sądu. Pozostało jeszcze wyegzekwowanie nakazu sędziego, ale minęła już groźba, że uciekinier zostanie przewieziony do kraju ${ }^{18}$. Wysiłek różnych osób zakończył się ostatecznie uwolnieniem zbiega. Wychodźstwo mogło to uznać za swój sukces.

Od początku w obronę Klimowicza zaangażowała się redakcja „Dziennika Polskiego i Dziennika Żołnierza”. Emigracyjna gazeta odegrała kluczową rolę w nagłośnieniu sprawy „ślepego” pasażera ze statku „Jarosław Dąbrowski”. O „tajemniczej” próbie ucieczki z polskiego statku londyński „Dziennik Polski” po raz pierwszy pisał w numerze z 31 lipca ${ }^{19}$. W następ-

1836 godzin dramatycznej walki, DPDŻ 1954, 182, s. 1, 4; Uwagi. Antoni Klimowicz, „Robotnik" 1954, 6, s. 2; K. Głuchowski, W polskim Londynie 1947-1970, Londyn 1999, s. 111114. Zob. też: AMSZ, D III, z. 9, w. 30, t. 389, Notatka służbowa K. Maciejkowicza, k. 8; ibidem, Raport M. Głowackiego, k. 11. Zbiegiem okoliczności w drodze powrotnej oprócz Klimowicza dodatkowym pasażerem na statku „Jarosław Dąbrowski” był również doktor Joseph Cort wraz z żoną Ruth, znany amerykański fizjolog. Od kilku lat mieszkał w Wielkiej Brytanii, gdzie pracował na uniwersytecie w Cambridge. Cort oskarżany za oceanem o działalność komunistyczną odmówił powrotu do ojczyzny (podczas studiów na uniwersytecie Yale należał do Komunistycznej Partii Stanów Zjednoczonych). Gdy władze brytyjskie nie przedłużyły mu prawa pobytu na Wyspach, otrzymał azyl w Czechosłowacji. Sprawa Corta wywołała zainteresowanie angielskich dziennikarzy. Kilku z nich przyszło na nabrzeże. Przy okazji dowiedzieli się również o Klimowiczu, zob. J. Rawicz, Dlaczego dr Cort jedzie do Czechosłowacji, „Trybuna Ludu” (dalej: TL) 1954, 216, s. 2.

${ }^{19}$ Zbieg nie zdołał zejść na ląd, DPDŻ 1954, 181, s. 1, 4. 
nych dniach redakcja na bieżąco informowała o przebiegu dramatycznej walki o wolność dla młodego Polaka.

Po uwolnieniu Klimowicz został odwieziony policyjną motorówką na komisariat w Erith. Przed komisariatem, pomimo późnej pory, czekała grupa Polaków oraz Brytyjczycy. Nikomu nie pozwolono jednak rozmawiać ze zbiegiem. Policja nie ujawniła też miejsca pobytu młodego Polaka. Dramatyczne okoliczności uwolnienia niedoszłego uciekiniera wywołały wielkie zainteresowanie nie tylko wśród polskich emigrantów, ale także miejscowej prasy. O sprawie Klimowicza pisały główne brytyjskie dzienniki. Prasa ujawniła również, iż mimo weekendu w sprawę tę zaangażowani byli czołowi politycy brytyjscy. Premier Churchill przebywający w swojej wiejskiej rezydencji telefonicznie miał wydać zgodę na zatrzymanie polskiego statku. Uwolnienia polskiego marynarza domagali się również brytyjscy związkowcy (zwłaszcza dokerzy) skupieni w organizacji Transport and General Workers Union ${ }^{20}$.

Ambasador Milnikiel, oceniając sprawę, nie miał najmniejszej wątpliwości, że „strona angielska poszła na ordynarną awanturę, pogwałciła zwyczaje i prawo międzynarodowe. Uczyniła to zarówno pod naciskiem polskich kół emigracyjnych, [jak i] w chęci przypodobania się Amerykanom". Polski dyplomata zastanawiał się nawet, czy w odpowiedzi „nie pójść na ryzyko odwołania Ambasadora" ${ }^{21}$. W centrali MSZ taki krok uznano jednak za zbyt drastyczny.

Rozprawa sądowa wyznaczona na 3 sierpnia trwała zaledwie kilka minut. Sędzia ogłosił, że przeciwko Klimowiczowi nie toczy się żadne postępowanie, co oznaczało, iż jest on wolnym człowiekiem. Mecenas Jaxa-Dębicki, który z ramienia SPK sprawował prawną opiekę nad zbiegiem, wyjaśniał dziennikarzom, że Klimowicz znalazł się w sytuacji cudzoziemca, który wylądował w Wielkiej Brytanii bez właściwych dokumentów. O udzieleniu uciekinierowi azylu zadecydować miał minister spraw wewnętrznych. Policja nadal nie ujawniła miejsca, w którym Polak przebywał ${ }^{22}$.

Sprawa uciekiniera nie schodziła z łamów emigracyjnej i angielskiej prasy. W kołach dziennikarskich pojawiły się nawet pogłoski, że musi on być jakimś znaczącym agentem brytyjskich służb specjalnych, a nie zwykłym marynarzem, skoro do jego uwolnienia użyto znacznych sił policyjnych $^{23}$.

\footnotetext{
${ }^{20}$ Klimowicz uratowany, s. 4; Klimowicz dziś stanie przed sądem, DPDŻ 1954, 183, s. 1, 4.

${ }^{21}$ AMSZ, D III, z. 9. w. 30, t. 389, Pismo E. Milnikiela do MSZ z 1 VIII 1954, k. 71-73.

${ }^{22}$ Klimowicz wolny - czeka na azyl, DPDŻ 1954, 184, s. 1, 4.

${ }^{23}$ Dlaczego aż 120 policjantów na „Dąrowskim”, DPDŻ 1954, 185, s. 1, 4.
} 
Przeciwko postępowaniu władz brytyjskich protestowały władze PRL. 3 sierpnia MSZ wystosowało notę do ambasady Wielkiej Brytanii w Warszawie. Nota zarzucała policji, że pod osłoną nocy, w wyniku brutalnego postępowania, uprowadziła ze statku ,ślepego" pasażera, podejrzanego o popełnienie w Polsce szeregu przestępstw kryminalnych. Władze PRL domagały się wydania Klimowicza, wynagrodzenia szkód powstałych w wyniku przetrzymania statku, napaści policji, zranienia i pobicia marynarzy oraz ukarania winnych. Nota opublikowana została również w krajowej prasie ${ }^{24}$.

Natychmiast odezwało się również brytyjskie MSW. W specjalnym oświadczeniu Home Office zaprzeczało zarzutom o brutalne zachowanie policji. Wyjaśniano, iż policja, wkraczając na statek w nocy 31 lipca, użyła siły jedynie w dwóch wypadkach: „gdy ktoś na statku poza podżeganiem załogi do zaatakowania policji sam zaatakował policjanta,który zmuszony był do użycia swej pałki w obronie własnej”. Załoga usiłowała również przeszkodzić policji w zabraniu Klimowicza z miejsca, gdzie był zamknięty, „lecz w tym wypadku nie użyto pałki”. W komunikacie zwracano uwagę na wrogą wobec policjantów postawę załogi polskiego statku. Gdy policjanci opuszczali statek, członkowie załogi obrzucali ich różnymi przedmiotami i wylali wiadro gorącej wody na jedną z łodzi policyjnych, stojących koło statku ${ }^{25}$.

Sprawę Klimowicza nagłośniły również władze PRL. Krajowa prasa $\mathrm{z}$,Trybuną Ludu” na czele w następnych dniach publikowała protesty polskich marynarzy, stoczniowców i robotników portowych przeciwko „brutalnej napaści” policji brytyjskiej, ,pobiciu załogi” statku „Jarosław Dąbrowski” oraz „uprowadzeniu siłą ze statku po wyłamaniu drzwi przestępcy kryminalnego - Klimowicza" ${ }^{26}$. Inspirowana odgórnie akcja miała pokazywać, że ogół robotników utożsamia się z polityką władz PRL, a tylko przestępcy uciekają z kraju. Potępienie zbiega miało też zniechęcać jego potencjalnych naśladowców.

Elementem antybrytyjskiej kampanii była wypowiedź Manfreda Lachsa, dyrektora Departamentu Prawno-Traktatowego w MSZ. W wywiadzie

${ }^{24}$ AMSZ, D III, z. 9, w. 30, t. 389, Nota MSZ z 3 VIII 1954, k. 32-38. Zob. też Przeciw naruszeniu w porcie brytyjskim praw bandery polskiej. Nota protestacyjna Rządu Polskiego, TL 1954, 216, s. 2.

${ }^{25}$ AMSZ, D III, z. 9, w. 30, t. 389, Tłumaczenie oświadczenia Home Office, k. 64; ibidem, Notatka służbowa z 7 VIII 1954 w sprawie zbiega Klimowicza, k. 43-44. Zob. też W. Brytania odrzuca oszczerczy protest reżymu, DPDŻ 1954, 186, s. 1, 4.

${ }^{26}$ Przeciw brutalnemu pogwałceniu praw polskiej bandery, TL 1954, 217, s. 1; Polscy marynarze, portowcy i stoczniowcy protestuja przeciw brutalnej napaści, TL 1954, 218, s. 1; Przeciw brutalnej napaści, TL 1954, 219, s. 1; Załogi polskich statków piętnują sprawców napaści na s/s „Jarosław Dąbrowski”, TL 1954, 221, s. 2; Protesty marynarzy w zwiazku napaścia na s/s ,Jarosław Dąbrowski”, TL 1954, 222, s. 2. 
dla „Trybuny Ludu” Lachs, występując jako profesor prawa międzynarodowego, działania władz brytyjskich nazwał ,aktem gwałtu i bezprawia"27.

$\mathrm{Na}$ polecenie z MSZ członkowie Wojewódzkiej Rady Narodowej w Gdańsku odmówili udziału w przyjęciu wydanym przez konsula brytyjskiego w tym mieście. Nie zgodzili się również na wizytę ambasadora Wielkiej Brytanii w hotelu robotniczym, „,o nie wchodzi - jak wiadomo - w normalny program zwiedzania miasta". Prośbę konsula o pomoc w zorganizowaniu wizyty ambasadora $\mathrm{w}$ gdańskim muzeum zbyto uwagą, że „Muzeum to jest powszechnie dostępne dla zwiedzających w normalnych godzinach"28.

Załoga statku „Jarosław Dąbrowski” po powrocie do Polski została nagrodzona „za godną postawę”. Kapitan M. Głowacki otrzymał Złoty Krzyż Zasługi, czterech marynarzy odznaczonych zostało srebrnymi, a dwóch brązowymi Krzyżami Zasługi ${ }^{29}$.

Zachowanie i postawę załogi polskiego statku pozytywnie ocenił wicekonsul Maciejkowicz. Według niego kierownictwo statku oraz cała załoga „wykazała wysoką świadomość polityczną", a działania władz brytyjskich spotkały się „z ogólnym potępieniem ze strony załogi”. Polski dyplomata podkreślił: „Kierownictwo statku było w stałym kontakcie z Konsulatem Generalnym, jak również ściśle się stosowało do poleceń i wytycznych tutejszej Placówki. Według opinii tutejszego Urzędu załoga statku s/s «J. Dąbrowski» zasługuje na pełne uznanie" ${ }^{30}$.

Sprawa Klimowicza budziła niegasnące zainteresowanie prasy brytyjskiej. Nielegalny pasażer ze statku „Jarosław Dąbrowski” nieoczekiwanie dla siebie stał się przedmiotem międzynarodowego sporu. Opublikowanie noty polskiego MSZ i oświadczenia Home Office przyczyniło się do podtrzymania tematu. Zaostrzył się również ton polemik w obu krajach. W prasowych komentarzach na Wyspach, odrzucając zarzuty władz PRL, podkreślano zasługi polskich emigrantów dla uwolnienia zbiega ${ }^{31}$.

6 sierpnia Home Office przyznało zbiegowi bezterminowo prawo pobytu w Wielkiej Brytanii. Dwa dni później Klimowicz po raz pierwszy zabrał publicznie głos. Bohater ostatnich dni wystąpił na konferencji prasowej zorganizowanej przez SPK. Spotkanie wywołało wielkie zainteresowanie mediów. Na rozmowę z Klimowiczem przyszło ponad stu

${ }^{27}$ Akt gwałtu i bezprawia, TL 1954, 219, s. 2.

${ }^{28}$ AMSZ, D III, z. 9, w. 30, t. 389, Tekst pisma WRN w Gdańsku przedyktowany telefonicznie 5 VIII 1954 z MSZ, k. 40.

${ }^{29}$ Za godna postawę. Marynarze s/s "Jarosław Dąrowski" otrzymali odznaczenia państwowe, TL 1954, 219, s. 1.

${ }^{30}$ AMSZ, D III, z. 9, w. 30, t. 389, Notatka służbowa K. Maciejkowicza, k. 9.

${ }^{31}$ Coraz ostrzejsza polemika o Klimowicza, DPDŻ 1954, 187, s. 1, 4. 
brytyjskich i amerykańskich dziennikarzy prasowych, radiowych oraz telewizyjnych. Konferencje prowadził redaktor Horko, który tłumaczył pytania i odpowiedzi. Klimowicz, niezrażony błyskiem fleszy oraz obecnością kamer, opowiadał o swojej dotychczasowej pracy, służbie wojskowej, motywach ucieczki (uciekł, bo jak podał, nie chciał być konfidentem UB), o tym, jak ukrył się na statku i jak odzyskał wolność. Mówił też o swoich planach na przyszłość: chciałby podjąć pracę w brytyjskiej marynarce handlowej. Fragmenty konferencji w wieczornych wiadomościach nadała stacja BBC. Program 3 angielskiego radia nadał specjalną audycję 25 minut z Klimowiczem ${ }^{32}$.

Komentując wydarzenia ostatnich dni, redakcja „Dziennika Polskiego i Dziennika Żołnierza” stwierdziła: „W sprawie Klimowicza Polonia angielska nagrodzona została pięknie za swe trudy. Miała też, przyznajmy, bardzo wiele szczęścia” ${ }^{33}$. Według felietonisty londyńskiego „Dziennika Polskiego", Zygmunta Nowakowskiego, Klimowicz na zrealizowanie swojego planu nie mógł „wybrać” gorszej pory - weekend i Bank Holiday: „Działał jakby na złość sobie samemu, w każdym razie na przekór naturze angielskiej”. Uwalniając polskiego marynarza, Anglia udowodniła jednak, że „ceni wolność jednostki i ratuje tę wolność”. Nowakowski wyrażał nadzieję, że Anglicy wykażą podobną gorliwość również wtedy, „gdy w grę wchodzi wolność nie tylko jednostek, ale całych narodów". Pochwalił także emigracyjne organizacje społeczne za błyskawiczną reakcję i zorganizowanie: „Organizacje społeczne pokazały, co potrafią. Nie tylko krzyk, ale i pomoc prawna, ale i interwencje wszędzie, gdzie się dało. I te interwencje postawiły na nogi Anglików, zbudziły ich ze snu weekendowo-holidejowego. Cud prawdziwy". Sprawa Klimowicza przyczyniła się również do zainteresowania Brytyjczyków problemami polskich emigrantów: „Po raz chyba pierwszy na szpaltach gazet angielskich pojawił się termin «Free Poles». Po raz pierwszy nasi gospodarze w sposób tak intensywny zainteresowali się nami, liczbą Polaków, ich organizacją, ich sprawnością"34.

$\mathrm{Na}$ odpowiedź Foreign Office na polską notę z 3 sierpnia trzeba było czekać prawie trzy tygodnie. Ambasador Andrew Noble osobiście wręczył ją 23 sierpnia w MSZ. Wyjaśniając postępowanie władz brytyjskich, stwierdził, iż oparły się one na precedensie z XVIII w., kiedy to na

${ }^{32}$ Jak wydostałem się na wolność, DPDŻ 1954, 188, s. 1, 4; S. Benedykt, Rozmowa z Klimowiczem, „Orzeł Biały” 1954, 33/34, s. 4; P. Heciak, Dwa dni pobytu z „Klimem”, „Gazeta Niedzielna" 1954, 34, s. 1-2; AMSZ, D III, z. 9, w. 30, t. 389, Wyciąg korespondencyjny z Londynu z 9 VIII 1954, k. 45.

33 „Niejaki” Antoni Klimowicz, DPDŻ 1954,189, s. 2.

${ }^{34}$ Z. Nowakowski, Klimowicz wyzwolony, DPDŻ 1954, 191, s. 2. 
zasadzie prawa Habeas Corpus zdjęto ze statku w porcie angielskim niewolnika, który uprzednio zbiegł na terytorium angielskie, później zaś został doprowadzony siłą na statek. Noble zapowiedział, że nota, podobnie jak polski dokument, zostania opublikowana. Podkreślił jednak, że „rząd brytyjski nie zamierza nadawać całej sprawie rozgłosu, ponieważ uważa incydent związany z osobą Klimowicza za sprawę małej wagi, która nie powinna w dalszym ciągu wpływać na stosunki między obu krajami". W trakcie godzinnej rozmowy z Bohdanem Lewandowskim, dyrektorem Departamentu III MSZ, Noble jeszcze kilkakrotnie zaznaczył, że „nie jest intencją rządu brytyjskiego dalsze rozwlekanie sprawy, która w końcu dotyczyła mało ważnej osoby". Lewandowski z satysfakcją przyjmując słowa ambasadora, wyraził zdziwienie, że „dopiero teraz zaczyna w stanowisku rządu angielskiego przebijać głos rozsądku. Jest to dość późno, ponieważ szkody wyrządzone przez akcję władz brytyjskich, a równocześnie rozgłos, jaki całej sprawie nadała prasa brytyjska, mogą być dosyć znaczne”. Polak, pytając retorycznie, „,kto był zainteresowany w rozdmuchaniu sprawy Klimowicza do takich rozmiarów, jakich byliśmy świadkami", sugerował jej związek z azylem dla doktora Josepha Corta i udział czynników amerykańskich. Noble, zasłaniając się tajemnicą służbową, zapewniał, że „Amerykanie na pewno nie mieli z tym nic wspólnego". Dodał, że w sprawie Klimowicza istotną rolę odegrali londyńscy dokerzy. Ich organizacja związkowa wywarła nawet nacisk na brytyjskich parlamentarzystów ${ }^{35}$. Choć w sprawie Klimowicza Anglicy trwali przy swoim stanowisku, to wyraźnie zależało im jednak na ociepleniu stosunków Warszawą.

W nocie Foreign Office wskazywano, iż kapitan polskiego statku, na którym przetrzymywany był Klimowicz, nie chciał zagwarantować wykonania nakazu doprowadzenia uciekiniera do sądu w dniu 3 sierpnia. W tej sytuacji policja, zgodnie z instrukcjami ministra spraw wewnętrznych, przeszukała statek, zabrała Klimowicza z miejsca, gdzie był przetrzymywany pod zamknięciem, i wyprowadziła go na brzeg: „Postawa kapitana - podkreślono - jego odmowa dania jakiegokolwiek zapewnienia, że zastosuje się do nakazu o Habeas Corpus, stworzyły konieczność zdjęcia Klimowicza ze statku nie czekając do 3 sierpnia, ponieważ nie można byłoby zgodzić się na to, by petent został wyjęty spod jurysdykcji, zanim jego prośba o azyl została zbadana" ${ }^{36}$.

${ }^{35}$ AMSZ, D III, z. 9, w. 30, t. 389, Notatka z 23 VIII 1954 z rozmowy z ambasadorem W. Brytanii p. Noble'm, k. 49-52.

${ }^{36}$ Ibidem, Tłumaczenie noty Foreign Office z 23 VIII 1954, k. 59-63.Zob. też: Klimowicz prosząc o azyl znalazł się pod jurysdykcją brytyjska, DPDŻ 1954, 203, s. 1, 4. 
W Warszawie długo zastanawiano się nad odpowiedzią. Po miesiącu $z$ ubolewaniem stwierdzono, że noty brytyjskiej nie można uznać za zadowalającą. Polemizując ze stanowiskiem Londynu, ponownie uznano, iż akcja władz brytyjskich była sprzeczna z prawem i zwyczajami międzynarodowymi ${ }^{37}$.

Anglicy nie toczyli już dłużej polemiki w sprawie Klimowicza. Wprawdzie ostatnie w niej słowo należało do władz PRL, nie wpłynęło to jednak na sytuację polskiego uciekiniera. Zresztą wkrótce pojawił się nowy problem. Tak się złożyło, że tego samego dnia, w którym MSZ odpowiedziało na notę brytyjską, doszło do buntu na trawlerze „Puszczyk”, który łowił śledzie na Morzu Północnym. Po opanowaniu statku siedmiu polskich rybaków dopłynęło do Wielkiej Brytanii, gdzie wystąpili o udzielenie im azylu politycznego. Sprawa ciągnęła się kilka następnych tygodni. Ostatecznie marynarze ci otrzymali azyl polityczny na Wyspach, a Klimowicz był jednym ze świadków obrony na ich procesie ${ }^{38}$.

Sprawa Klimowicza pozwalała na wysnucie krzepiącego dla emigrantów wniosku, iż „,wolny świat nie jest obojętny na dolę ludzi wyrywających się z sowieckiej niewoli na wolność; z drugiej jednak strony po raz nie wiadomo który została podkreślona zasada, iż skutecznie działa społeczność zorganizowana”. Choć dla uwolnienia Klimowicza „pożądana i cenna była pomoc obcych”, to jednak „kierownictwo akcji i pilnowanie sprawy od początku do końca pozostawały w rękach polskich" 39 . Szczęśliwy finał „bitwy” o Klimowicza dawał nadzieję i dowartościowywał wychodźstwo.

Emigracyjny „Robotnik” w komentarzu stwierdził: „Można powiedzieć, że cała potęga imperium brytyjskiego uruchomiona została w tym celu, by ocalić zagrożoną wolność jednego człowieka... [--] Tak, sprawa Antoniego Klimowicza była wielką lekcją respektu dla praw człowieka, niepozornej jednostki ludzkiej, a nie żadnej znakomitości. Widzieliśmy policję i marynarkę wojenną zmobilizowaną dla ochrony tych praw, a nie dla ich gwałcenia. Zaniesiemy z sobą pamięć tej wielkiej lekcji do Polski, gdy już będzie wolna"40.

Na jeszcze inne aspekty tego zagadnienia uwagę zwrócił badacz stosunków polsko-brytyjskich.Jan Linowski trafnie zauważył: „Wydanie Klimowicza władzom PRL byłoby pewnym sukcesem komunistów i uzasadniałoby propagandową plotkę, iż nie warto uciekać, bo władza jest tak

${ }^{37}$ AMSZ, D III, z. 9, w. 30, t. 389, Nota MSZ z 22 IX 1954, k. 68-70.

${ }^{38}$ Szerzej na temat marynarzy z „Puszczyka”: K. Tarka, op. cit., s. 115-132. Zob. też: AMSZ, D III, z. 9, w. 34, t. 450.

${ }^{39}$ L. B., Klimowicz i Danieluk, DPDŻ 1954, 206, s. 3.

${ }^{40}$ Uwagi. Antoni Klimowicz, s. 2. 
potężna, że każdego zbiega potrafi ująć. Podkopałoby też zaufanie części społeczeństwa polskiego do państw zachodnich, iż mogą zapewnić azyl każdemu, kto opuszcza kraj w obawie przed represjami" ${ }^{41}$.

Przed ucieczką Klimowicz mieszkał wraz z rodzicami i ciężko chorym bratem Henrykiem w Gdyni przy ulicy Kwidzyńskiej. Po latach jego starszy brat Kazimierz, również mieszkający w Gdyni, ale pod innym adresem, opowiadał reporterce „Dziennika Bałtyckiego”, że na początku sierpnia 1954 r. w domu rodzinnym Klimowiczów milicja przeprowadziła przeszukanie. Rodzice i bracia Antoniego byli też przesłuchiwani. Pozbawiono ich również mieszkania. Musieli się przeprowadzić do Malborka. Po 1956 r. wrócili do Gdyni, ale mieszkania już nie odzyskali. Antoni Klimowicz z Wielkiej Brytanii wyjechał do Stanów Zjednoczonych. Zamieszkał w Clifton w stanie New Jersey, gdzie pracował jako kierowca. Nie ożenił się. Rodzinną Gdynię odwiedził dopiero na początku lat osiemdziesiątych. Wcześniej bał się, że jako uciekinier może zostać aresztowany po przyjeździe do kraju. Zmarł 5 maja $1987 \mathrm{r}^{42}$

\section{Battles for Freedom. The Case of the Escape of Antoni Klimowicz in 1954}

From the legal point of view the case of Antoni Klimowicz, a stowaway on s.s "Jarosław Dąbrowski", was extremely complex. The escape of the young Pole in July 1954 influenced Polish-British relations and mobilised Polish émigré circles in the UK. The illegal passenger was discovered by British dock workers unloading the ship. Initially, everything appeared to indicate that the attempted escape would end badly for him. "Jarosław Dąbrowski" with Klimowicz on deck had already sailed from the Port of London, but soon was halted by the police pursuing it down the Thames. The British, evoking the Habeas Corpus Act, demanded that Klimowicz be handed over to them, and the ship's captain protested. In this situation, police officers resorted to force and "rescued" the fugitive. The chief role in freeing Klimowicz was played by the Polish émigrés in the UK, who acted in his defence. The Polish Embassy and authorities unsuccessfully protested against the conduct of the British. For several days the case of the Polish runaway was discussed in the émigré and British press. Ultimately, Klimowicz was granted political asylum and subsequently left for the USA, where he died.

Translated by Aleksandra Rodzińska-Chojnowska

\footnotetext{
${ }^{41}$ J. Linowski, op. cit., s. 245.

${ }^{42}$ D. Abramowicz, op. cit., s. 19.
} 